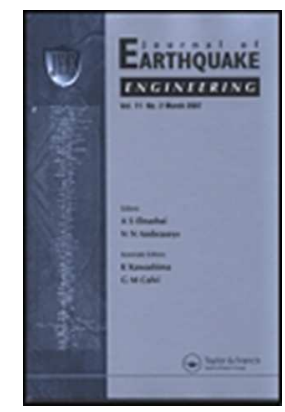

\title{
Masonry Italian code-conforming buildings: Part 1: case studies and design methods
}

\begin{tabular}{|r|l|}
\hline Journal: & Journal of Earthquake Engineering \\
\hline Manuscript ID & Draft \\
\hline Manuscript Type: & Full Length Papers \\
\hline Complete List of Authors: & $\begin{array}{l}\text { Manzini, Carlo; Eucentre } \\
\text { Magenes, Guido; University of Pavia, Department of Structural } \\
\text { Mechanics; } \\
\text { Penna, Andrea; EUCENTRE, Masonry Structures and Monuments } \\
\text { da Porto, Francesca; UNIPD, DICEA } \\
\text { Camilletti, Daniela; University of Genoa, DICCA } \\
\text { Cattari, Serena; University of Genova, DICCA } \\
\text { Lagomarsino, Sergio; University of Genoa, DICCA }\end{array}$ \\
\hline Keywords: & $\begin{array}{l}\text { URM buildings, seismic design, linear static analysis, nonlinear static } \\
\text { analysis, simple buildings rules }\end{array}$ \\
\hline
\end{tabular}




\section{Masonry Italian code-conforming buildings: Part 1: case studies and design methods}

Carlo F. Manzini ${ }^{\mathrm{a}}$, Guido Magenes ${ }^{\mathrm{a}, \mathrm{b}}$, Andrea Penna ${ }^{\mathrm{a}, \mathrm{b}}$, Francesca da Porto ${ }^{\mathrm{c}}$, Daniela Camilletti ${ }^{\mathrm{d}}$, Serena Cattari ${ }^{\mathrm{d}}$, Sergio Lagomarsino ${ }^{\mathrm{d}, *}$

${ }^{a}$ EUCENTRE Foundation, Pavia, Italy; ${ }^{b}$ Department of Civil Engineering and Architecture, University of Pavia, Pavia, Italy; ${ }^{c}$ Department of Civil, Architectural and Environmental Engineering, University of Padua, Padua, Italy; ${ }^{d}$ Department of Civil, Chemical and Environmental Engineering, University of Genoa, Genoa, Italy

*corresponding author: sergio.lagomarsino@unige.it 


\title{
Masonry Italian code-conforming buildings: Part 1: case studies and design methods
}

\begin{abstract}
Various architectural configurations of URM residential buildings are designed according to the different methods the Italian code: rules for the so-called simple masonry buildings, linear and nonlinear static analyses. Always complying with code requirements, for each building-site combination the design was made, as much as possible, without an excessive margin of safety. The different design methods provided buildings with very different levels of safety, being linear static analysis largely overconservative with respect to the nonlinear static approach. These buildings were then analyzed in the companion paper by Cattari et al. (2018).
\end{abstract}

Keywords: URM buildings, seismic design, linear static analysis, nonlinear static analysis, simple buildings

\section{Introduction}

The RINTC Project aims at the evaluation of the level of seismic risk implicit in buildings designed according to the Italian building code of 2008 (NTC08, 2008), as discussed in depth in Iervolino et al. (2018). Within this framework, different new building typologies were considered, including reinforced concrete (r.c.) buildings (Ricci et al. 2018, Terrenzi et al. 2018), steel buildings (Scozzese et al. 2018), precast structures (Magliulo et al. 2018), seismically isolated buildings (Ragni et al. 2018) and unreinforced masonry (URM) buildings. The latter is still the most commonly adopted solution for structural masonry in Italy, although reinforced masonry is also an option.

It should be mentioned that an updated version of the Italian building code has been released in 2018 (NTC18, 2018), with minor differences in terms of seismic design prescriptions for URM structures. 
In newly designed URM buildings, the architectural conception typically governs the wall distribution and few degrees of freedom are left to the structural designer. Apart from some code constrains (maximum wall slenderness, minimum distance between one opening and the end of the wall, etc.), the architect plans the geometry of the construction based on different factors and even the choice of the type of masonry units can be governed by non-structural reasons (e.g. energy efficiency).

Very often, this results in a "complex" structure, frequently with a mixed URMr.c. structure. Therefore, in most cases, the task of the structural engineer is to assess the seismic performance of the conceived building, rather than a free design of the structure, unless major structural simplifications are deemed necessary (e.g. when very irregular buildings need to be subdivided into regular structural portions, Tomaževič 1999).

In this work, reference was made to the prescriptions of NTC08, which were somehow derived from Eurocode indications (EC6, EN1996-1-1, 2004, EC8-1, EN19981, 2004) and integrated with some beneficial concepts introduced from EC8-3 (EN19983, 2005), for the analysis of masonry buildings (e.g. DeJong and Penna, 2016). As a result of this process, the prescription of NTC08 for the seismic design of URM structures are significantly more detailed than Eurocode 8. Differences between Eurocodes and NTC08 as well as additional prescriptions reported in the Italian code are highlighted in the next sections.

URM buildings with six different in plan architectural configurations, assumed to be representative of typical Italian residential buildings, were verified using the different methods and rules of NTC08 for new buildings. These configurations show some common features concerning materials, structural details, number of stories and typology of diaphragms and roofs, selected among those most commonly adopted for newly constructed URM buildings. They obviously do not encompass the whole variability of 
URM structures, which include the possible use of different types of units, mortars, joints, structural details etc. The choice of vertically perforated clay blocks (with void ratio lower than $45 \%$ of the block volume), which is the most commonly adopted typology for loadbearing masonry in Italy, is also supported by the availability of a large database of experimental tests allowing the calibration of the refined model adopted in the assessment phase reported in the companion paper (Cattari et al., 2018). In general, the adoption of other masonry typologies (e.g. aerated autoclaved concrete or lightweight aggregate concrete blocks), all complying with code requirements, would not affect the "design" phase, although some differences in the risk assessment phase may result from a possibly different in-plane drift capacity of masonry piers (Salmanpour et al. 2013, Petry and Beyer 2014, Gams et al. 2016, Snoj and Dolšek 2017, Morandi et al. 2018).

The methods most often used in engineering practice were selected for the design, respecting the provisions of NTC08 and ensuring compliance with the safety checks at the life-safety limit state. The selected structural configurations were verified, with the different methods, for five sites with different levels of seismic hazard (L'Aquila, Naples, Rome, Caltanissetta and Milan, respectively "AQ", "NA", "RM", "CL" and "MI" in the following) and two soil types (A and C, according to NTC08) were considered (Iervolino et al. 2018). Table 5 reports the design peak ground acceleration values for the return period of 475 years (hazard level adopted in the code for the design of residential buildings at life-safety limit state) for the considered soil conditions at the different sites selected to represent the variability of seismic hazard in Italy. For each building-site combination, meaningful designs were identified, consisting in cases in which the building barely complies with code requirements, i.e. it satisfies the different safety checks and conditions without however being over-designed. 


\section{Design of URM Structures According to the Italian Building Code}

\subsection{Design Methods}

General prescriptions are indicated in the Italian building code (NTC08, 2008) for the design of new masonry buildings located in seismic areas with the aim of promoting both structural robustness and a box-type behavior. Basic requirements are related to structural materials (minimum strength for units and mortar, maximum percentage of voids in perforated units, arrangement of unit webs and shells, e.g. Tomaževič et al. 2006) and masonry assemblies (use of head-joints filled with mortar). Further requirements on the structural conception and detailing for URM structures are:

i) the presence of rigid diaphragms well connected to r.c. tie beams at each wall-tofloor intersection;

ii) limitations to the aspect ratios of masonry piers and to the maximum spacing between consecutive floors, to prevent instability and out-of-plane failure;

iii) limitations to the distance of openings from corners (not less than $1 \mathrm{~m}$ ) to guarantee an effective wall-to-wall connection;

iv) limitations to the thickness and the in-plane and out-of-plane aspect ratios of primary and secondary walls. The former should be able to withstand lateral loads, whereas the latter are designed simply to resist vertical loads and accommodate lateral deformation. Limit values for primary walls in NTC08 are the same recommended in EC8-1 for moderate-to-high seismicity sites (i.e. minimum thickness of $240 \mathrm{~mm}$, out-of-plane slenderness of 12, in-plane aspect ratio of 0.4 ), whereas they differ for low-seismicity areas (minimum thickness of $200 \mathrm{~mm}$, out-of-plane slenderness of 20, in-plane aspect ratio of 0.3 in NTC08, minimum thickness of $170 \mathrm{~mm}$, out-of-plane slenderness of 15, in-plane aspect ratio of 0.35 in EC8-1). 
Similarly to EC8, NTC08 allows the use of different analysis methods for the design/assessment of masonry buildings, namely:

- empirical rules applicable to the so-called simple masonry buildings (SB);

- linear static analysis (LSA);

- linear dynamic analysis (LDA);

- nonlinear static analysis (NLSA);

- nonlinear dynamic analysis (NLDA).

In this study, linear and nonlinear static analyses and rules for simple buildings were considered, since they represent the methods commonly used in the engineering practice. The choice of one or the other also depends on the seismicity level of the site under examination. Differently from other structural typologies, the NLSA is often used for the design, and not only for the assessment of existing buildings: this is due to the drawbacks of linear methods in case of a highly nonlinear material such as masonry, particularly in areas with high seismicity (e.g. Magenes 2006) and is favored by the availability of commercial software-packages specifically dedicated to URM buildings.

Dynamic analyses are not frequently used for the design of URM structures. Indeed, linear dynamic analysis (i.e. modal analysis with response spectrum), in addition to the intrinsic limitations of linear elastic models for masonry structures, is also not very significant for low-rise buildings with short fundamental period. On the other hand, nonlinear time history analysis is problematic at the engineering practice level, due to its computational burden and several issues related to the availability of cyclic hysteretic constitutive laws for masonry elements, the difficulties in the selection of the seismic input and the definition of limit states from time-history analysis results (e.g. Corigliano et al. 2012, Mouyiannou et al. 2014, Smerzini et al. 2014, Lagomarsino and Cattari 2015). 
While both LSA and NLSA require the definition of a structural model, the design according to the rules for simple masonry buildings is based on compliance with code provisions related to structural aspects, in terms of geometry, materials, structural details and minimum area of structural walls in two main directions. In addition, simple masonry buildings must be regular in plan and in elevation and should be no more than three stories high. Structural requirements for simple URM buildings include:

i) presence of at least two systems of shear walls in the two main orthogonal directions, each with a total gross length excluding openings not less than $50 \%$ of the total building length in the corresponding direction;

ii) at least $75 \%$ of vertical loads should be supported by shear walls;

iii) mean compression stress at each level not higher than $25 \%$ of the design masonry compressive strength;

iv) spacing between parallel walls not larger than $7 \mathrm{~m}$;

v) minimum ratios between area of shear walls and total floor area in both orthogonal directions are provided as a function of the number of storeys and the seismic intensity (expressed in terms of $a_{g} S$, being $a_{g}$ the reference design peak ground acceleration on soil type A and $S$ the soil amplification factor).

Condition i) is surely easier to be achieved than what is requested in EC8-1 for simple masonry buildings in moderate-to-high seismicity areas, i.e. the presence of "a minimum of two parallel walls placed in two orthogonal directions, with the length of each wall being greater than $30 \%$ of the length of the building in the direction of the wall under consideration" and "at least for the walls in one direction" a minimum distance between such walls "greater than $75 \%$ of the length of the building in the other direction". EC8-1, however, does not explicitly enforce regularity in plan and in elevation, but 
prescribes that plans of simple buildings should be approximately regular and that "shear walls should be continuous from the top to the bottom of the building."

The other conditions are consistent with the corresponding clauses in EC8, where, however, the values of several key parameters, including wall areas and corresponding seismic action, can be varied in each country through the National Application Documents (NADs).

When applying LSA, the structure is subjected to the application of a static force distribution equivalent to the inertial forces induced by the seismic action; then, the verification is performed, at the individual structural element level, in terms of strength. LSA assumes a linear behavior of the structure by implicitly considering the material nonlinearity through the behavior factor $q$, which reduces the acceleration response spectrum. In case of URM structures, the values for the $q$ factor proposed by the Italian code are obtained as a product of a basic value (equal to 2 for URM) and an overstrength factor, for which reference values are provided by the code as a function of the number of stories (1.4 for one-story buildings and 1.8 for two or more stories). EC8-1 recommends instead a behavior factor ranging from 1.5 to 2.5 , which is significantly lower than the corresponding range of NTC08 (2.8-3.6). This difference could be ascribed to the variability in geometrical configurations from country to country, strongly affecting the overstrength ratio (Magenes 2006). Both codes allow the use of pushover analysis for a specific evaluation of the overstrength factor. LSA can be applied also to buildings which are irregular in elevation.

The code allows the application of LSA also with force redistribution. The rules for its application depend on diaphragms deformability. In case of rigid diaphragms, the LSA with force redistribution allows to modify the base shear distribution in the walls of the same floor derived from a LSA, provided that global equilibrium is satisfied and the 
absolute variation of shear in each wall does not exceed a maximum value, depending on the shear force in the wall and the total story shear in the direction parallel to the wall. If diaphragms are flexible, force redistribution is limited to piers belonging to the same wall.

Finally, in case of NLSA, the nonlinear behavior of the building is directly included in the analysis and the structural capacity is expressed in terms of the so-called pushover curve. Different force distributions must be adopted (e.g. mass proportional and modal distribution), with and without consideration of the effect of accidental eccentricity due to irregular mass distribution. The verification is then performed at a global scale in terms of displacement, using the N2 method (Fajfar 2000), which is based on the use of inelastic spectra obtained through the reduction of the elastic spectrum by means of the $q^{*}$ parameter, depending on building ductility and initial period. The N2 method requires the conversion of the building pushover curve into the capacity curve of an equivalent nonlinear single-degree-of-freedom (SDOF) system, which is then approximated by a bilinear curve (e.g. Kalkan and Kunnath 2006, Causevic and Mitrovic 2011, Costa et al. 2011, De Luca et al. 2013). Indeed, it is worth reporting that recent studies showed that in the case of short period structures, as URM buildings, the N2 method tends to underestimate the expected seismic demand providing evaluations that are not always on the safe side (e.g. Miranda 1993, Whittaker et al 1998, Guerrini et al. 2017 and Marino et al. 2018 for further details). The N2 method adopted in EC8 includes the possibility of using either an iterative and a non-iterative procedure (with a single bilinear idealization of the capacity curve) for the evaluation of displacement demand, whereas in NTC08 only the non-iterative procedure is considered.

The ultimate displacement, defined on the pushover curve as the one corresponding to a post-peak strength drop of $20 \%$ of the maximum total base shear, is assumed to correspond to the life-safety (LS) limit state. Differently, in NTC18, similarly 
to EC8, this $20 \%$ drop is associated to the near collapse limit state and the safety checks for the ultimate limit state are recalibrated for the near collapse limit state, with a revision of the drift limits associated with the ultimate capacity of masonry piers (increased in NTC18 from $0.4 \%$ to $0.5 \%$ for shear failure and from $0.8 \%$ to $1.0 \%$ for in-plane bending failure).

The displacement capacity associated with the damage limitation (DL) limit state is defined as the minimum between the displacement corresponding to the maximum base shear and the one corresponding to an inter-story drift of $0.3 \%$. The latter value, which is hardly governing the definition of the limit state displacement, was reduced to $0.2 \%$ in NTC18. For both limit states, the verification consists in checking if the displacement demand induced by the seismic action is lower than the corresponding capacity, represented by these displacement thresholds. However, given the typically high stiffness of URM buildings and the relatively high displacement threshold at the DL limit state, the assessment according to NTC08 is usually driven by the LS conditions. This was the case also for the selected building configurations and hence results will be mainly discussed referring to the ultimate limit state (LS).

In case of NLSA, the Italian code specifies an additional requirement for the LS verification, i.e. that the $q^{*}$ factor cannot exceed the value of 3 , otherwise compromising the LS verification. Similarly, NTC18 set a maximum value of $q^{*}=4$, although referring to the near collapse limit state. The rationale behind this limitation is to prevent the evaluation of excessively large values of available ductility due to an incorrect estimate of the initial stiffness. On the contrary, EC8 provides a limit to the displacement demand of the inelastic system, equal to three times the demand of a linear system with the same initial period. A more detailed discussion on the limitations of the different analysis 
methods and the issues related with their application can be found for example in (Magenes 2010, DeJong and Penna 2016 and Marino et al. 2018).

\subsection{Modeling Strategies}

For the analysis methods requiring a structural model (LSA and NLSA), the NTC08 allows using both cantilever and equivalent frame models.

Cantilever model can be adopted if the diaphragms are infinitely rigid. In this case, the structural model only includes the masonry piers, which are continuous from the foundations to the top of the building, while spandrels are not explicitly modeled and their effect is only to couple the horizontal displacements of the piers at each level. On the other hand, in the equivalent frame approach, both piers and spandrels are introduced in the structural model and consequently included in the verification procedure. Each resistant masonry wall is subdivided into a set of deformable masonry panels (piers and spandrels), in which the deformation and the nonlinear response are concentrated, and of rigid nodes connecting the panels.

For the definition of the equivalent frame model, the code does not provide specific indications about all possible modelling choices, thus leaving room for the assumptions of the engineer. These choices include the definition of the effective geometry of the equivalent frame members (e.g. effective height of piers, effective length of ring beams, etc.), the loading scheme of the floors (subdivision of loads between walls parallel and orthogonal to spanning direction), the degree of connection of orthogonal walls (i.e. different strategies for modeling the flange effect), etc. As discussed more in detail in Cattari et al. (2018), these modelling assumptions can be regarded as a source of epistemic uncertainty, taking into account, for each aspect, the possible choices with appropriate weights. 
In the case of NLSA, the minimum modeling requirement of the code is the use of a bilinear elastic-perfectly plastic constitutive law for masonry panels and other structural members (e.g. r.c. columns, ring beams, etc.). Specific indications for the computation of stiffness, shear strength and ultimate displacement associated with the prevailing failure mode are also provided. In particular, the code suggests the use of cracked section properties (which, in case of masonry panels, can be appropriate even for low values of seismic action), obtained by applying a reduction coefficient (e.g. equal to 0.5 in the absence of more precise evaluations) to the lateral stiffness of the structural members. The out-of-plane response of masonry walls can be computed separately from the global response governed by the in-plane behavior. In newly-designed buildings, the systematic presence of r.c. tie beams at each wall-to-diaphragm connection and the limitation imposed to the maximum out-of-plane wall slenderness typically prevent the occurrence of out-of-plane failure mechanisms. On the other hand, in modernly conceived buildings, the contribution to the global strength and stiffness of out-of-plane loaded walls is negligible with respect to that of in-plane loaded walls. For this reason, some computer programs for the analysis of masonry buildings (e.g. 3Muri, Lagomarsino et al. 2013, STA Data 2017) neglect the out-of-plane stiffness contribution of walls, which can be instead explicitly considered in other programs (e.g. ANDILWall, Manzini et al. 2013). The lateral strength of each panel is determined as the minimum between the values associated with shear and flexural failure modes, computed with the simplified criteria proposed in the code (see e.g. Mann and Mueller 1982, Andreaus 1996, Magenes and Calvi 1997, Graubner and Kranzler 2006, Calderini et al. 2009, Tomaževič 2009, Jäger and Gams 2016, for a discussion on the main hypotheses behind these criteria), differentiated for piers and spandrels (Table 1). Mean values of the mechanical properties are used in case of NLSA. 
Similarly to the criterion proposed in EC6 (EN1996-1-1, 2004), the strength associated with the shear failure of piers is computed as the minimum between the shear strength corresponding to a Coulomb-type sliding on the bed-joints and the one associated with unit failure applied to the compressed portion of the cross section. The strength associated with the flexural failure mode is calculated neglecting the tensile strength of the material and assuming a stress block normal distribution at the compressed toe. The formula adopted in NTC08 is actually the same reported in EC8-3 for the assessment of existing masonry structures. In EC8-1, strength criteria are not reported, and reference is made to EC6, which does not include a specific strength formula for in-plane bending strength, although it specifies that the length of the compressed part of the wall should be verified for the vertical load applied to it and the vertical load effect of lateral loads. In case of spandrels, the strength corresponding to shear and flexural failure modes is calculated with similar formulas, modified to account for the different orientation of these structural members (see Table 1). If the horizontal compressive force acting on the spandrel is unknown and tensile resisting elements are coupled to the spandrel (e.g. r.c. tie beam), the spandrel behavior is interpreted according to a strut mechanism assuming the compressive force equal to the tensile strength of the coupled element. A complete review of in-plane strength criteria for masonry spandrels can be found in Beyer and Mangalathu (2013).

Table 1. Strength criteria for piers and spandrels included in NTC08.

\begin{tabular}{lcc}
\hline $\begin{array}{c}\text { Failure } \\
\text { mode }\end{array}$ & Piers & Spandrels \\
\hline Flexure & $M_{R}=\frac{\sigma_{0} t l^{2}}{2}\left(1+\frac{\sigma_{0}}{0.85 f_{m}}\right)$ & $M_{R}=H_{p} \frac{h}{2}\left(1-\frac{H_{p}}{0.85 f_{h} h t}\right)$ \\
\hline Shear & $V_{R}=l^{\prime} t f_{v}$ & $V_{R}=h t f_{v 0}$ \\
& &
\end{tabular}


$l:$ length of the cross section of the masonry panel

$t$ : width of the cross section of the masonry panel

$h$ : height of the cross section of the masonry panel

$l '$ : length of the compressed portion of the cross section

$f_{m}$ : masonry compressive strength

$f_{h}$ : masonry compressive strength in the horizontal direction;

$f_{v}=f_{v 0}+0.4 \sigma_{0} \leq f_{v l t}$, with $f_{v l t}$ limit shear strength associated with unit failure, $f_{v 0}$ initial shear strength

$\sigma_{0}$ : mean normal stress acting on the gross section of the panel;

$H_{p}$ : minimum between the strength of the tensile-resistant element coupled to the spandrel and $0.4 f_{h} h t$.

The attainment of the ultimate condition for the panels is determined by assuming a drift threshold equal to $0.4 \%$ and $0.6 \%$, in case of a prevailing shear and flexural failure modes, respectively.

\section{Selected Building Configurations and Design Output}

The designed building configurations are either two- or three-story unreinforced masonry buildings, made of vertically perforated clay units with head- and bed-joints filled with cement mortar joints.

The buildings have continuous r.c. ring beams at each level, at the intersection of floors and walls. One-way spanning mixed r.c. - hollow clay tile floor slabs were assumed (total thickness of $25 \mathrm{~cm}$, with top $5 \mathrm{~cm}$ of r.c. slab), being the most common practice in new residential masonry buildings in Italy.

The architectural configurations examined were indicated as "C", "E" and "I" buildings. "E" buildings represent examples (E) of real modern unreinforced masonry buildings, whereas the " $\mathrm{C}$ " configurations were conceived $(\mathrm{C})$ as structural variations of regular wall arrangements based on the same architectural plan, designed to barely comply with the safety requirements at the different sites and the "I" configurations incorporate the degrees of irregularity (I) allowed by the code.

Among the "E" type configuration, three (i.e. "E2", "E8" and "E9") are regular both in plan and in elevation, whereas one ("E5") is regular in elevation, but irregular in 
plan. For each "E" and "C" configuration, both two- and three-story buildings were designed, with identical architectural and structural configuration at all levels. For the "I" type configuration, two solutions were considered: a two-story building, "I1", regular in elevation and irregular in plan, and a three-story building, "I2", which is irregular both in plan and in elevation. The architectural configurations of the examined buildings are illustrated in Figure 1.

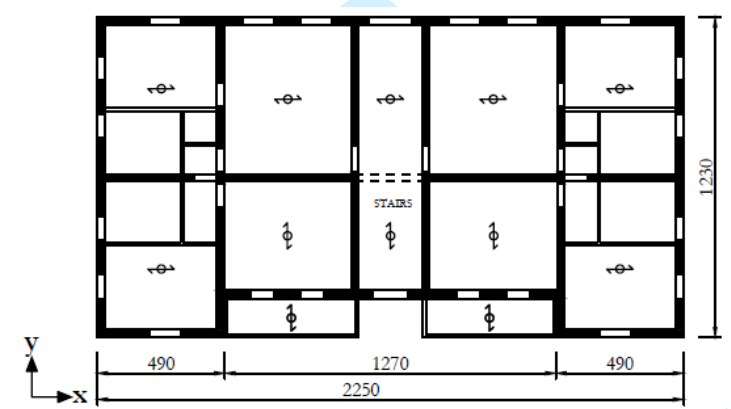

(C)

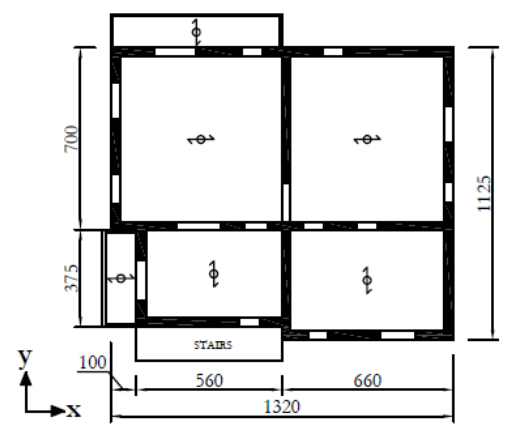

(E5)

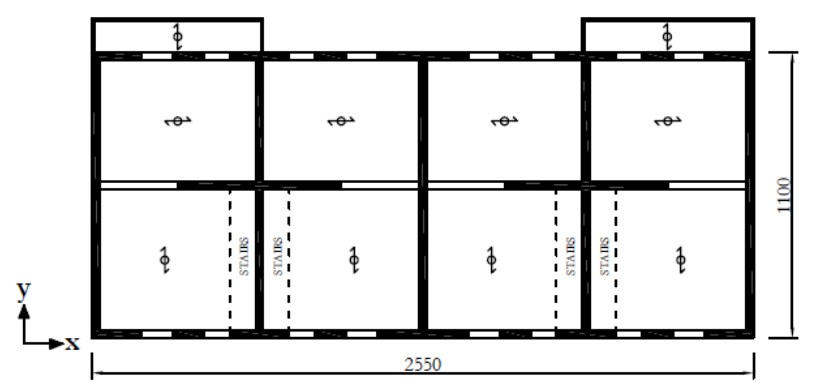

(E9)

Primary walls

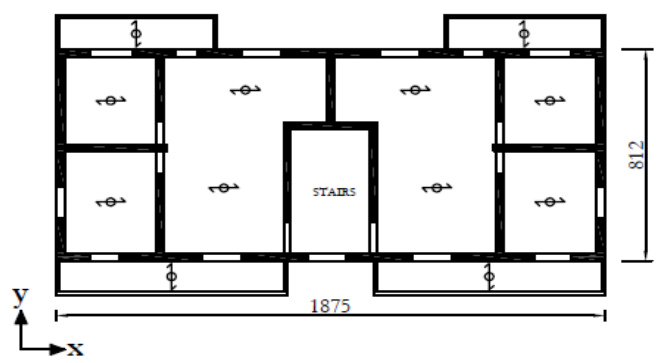

(E2)

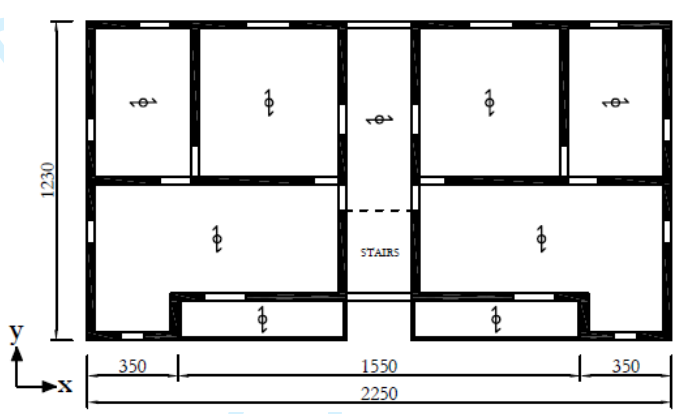

(E8)

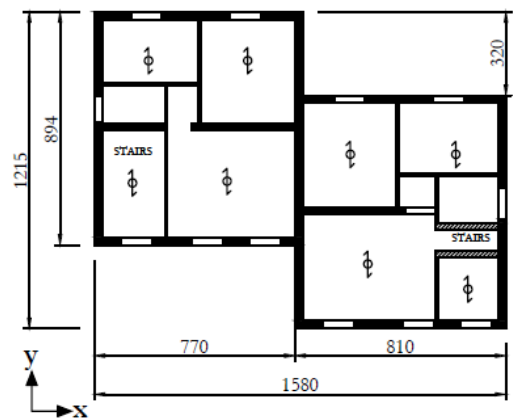

(I)

Partition walls

Figure 1. Selected architectural plan configurations (structural variations, namely $\mathrm{C} 1$ to C7, were then created starting from the reported " $C$ " type plan, derived in turn from E8) Dimensions in the plans are in $\mathrm{cm}$. 


\section{Structural Configurations According to the Different Design Approaches}

The six architectural plan configurations comply with the code general design criteria, geometrical requirements and construction details for URM buildings. In particular, attention was paid to satisfy the minimum dimensions of seismically resistant walls, the presence of a continuous concrete ring beam at each level (minimum gross section and minimum reinforcement were assumed) and the presence of at least $1 \mathrm{~m}$ long masonry wall portions at each corner intersection of external walls.

Regular building configurations satisfy the additional conditions required by the code for "simple masonry buildings", in terms of number, total length and transversal spacing of seismically resistant walls in each of the orthogonal directions, number of stories, minimum resistant area as a function of number of stories and level of seismic input, average compressive stress at each story.

The main geometrical characteristics of the designed buildings are summarized in Table 2.

Table 2. Main structural features of the selected architectural configurations.

\begin{tabular}{|c|c|c|c|c|c|c|c|}
\hline \multirow[t]{2}{*}{ Configuration } & \multirow[t]{2}{*}{ Buildings } & \multicolumn{2}{|c|}{ Regularity } & \multirow{2}{*}{\begin{tabular}{|c|} 
No. \\
of stories
\end{tabular}} & \multirow{2}{*}{$\begin{array}{c}\text { Inter- } \\
\text { story } \\
\text { height }\end{array}$} & \multicolumn{2}{|c|}{ Wall thickness } \\
\hline & & plan & elevation & & & $\begin{array}{c}\text { External } \\
\text { walls }\end{array}$ & $\begin{array}{c}\text { Internal } \\
\text { walls }\end{array}$ \\
\hline $\mathbf{C}$ & $\mathrm{C} 1$ to $\mathrm{C} 7$ & yes & yes & 2 and 3 & $3.10 \mathrm{~m}$ & $\begin{array}{c}30-40 \mathrm{~cm} \\
*\end{array}$ & $\begin{array}{c}25-35 \mathrm{~cm} \\
*\end{array}$ \\
\hline \multirow{3}{*}{$\mathbf{E}$} & E2 & yes & yes & 2 and 3 & $3.10 \mathrm{~m}$ & $30 \mathrm{~cm}$ & $25 \mathrm{~cm}$ \\
\hline & E5 & no & yes & 2 and 3 & $3.10 \mathrm{~m}$ & $35 \mathrm{~cm}$ & $30 \mathrm{~cm}$ \\
\hline & E8-E9 & yes & yes & 2 and 3 & $3.10 \mathrm{~m}$ & \multicolumn{2}{|c|}{$30 \mathrm{~cm}$} \\
\hline \multirow[b]{2}{*}{ 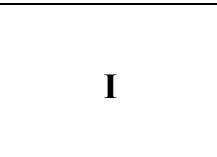 } & I1 & no & yes & 2 & $3.30 \mathrm{~m}$ & $30 \mathrm{~cm}$ & $\begin{array}{c}20 / 25 \mathrm{~cm} \\
* *\end{array}$ \\
\hline & I2 & no & no & 3 & $3.10 \mathrm{~m}$ & $30 \mathrm{~cm}$ & $\begin{array}{c}20 / 25 \mathrm{~cm} \\
* *\end{array}$ \\
\hline
\end{tabular}

* Wall thickness differs in each building of the same type configuration.

** The smaller value is referred to walls assumed to carry gravity loads only, the larger to walls resisting seismic action as well.

As mentioned above, the type "C" configurations were arranged to create different structural solutions, conceived to comply with the different analysis methods without 
being excessively over-designed (as illustrated in the following sections), starting from the same architectural plan. In particular, seven configurations were considered (denoted as "C1" to "C7"), starting from the base configuration sketched in Figure 1, with differences in the thickness of structural walls, to obtain different areas of shear walls as percentage of the total floor area. Furthermore, in " $\mathrm{C} 1$ " and "C2", some of the internal walls were replaced by r.c. beams and columns, to further reduce the area of shear walls (see Figure 2).

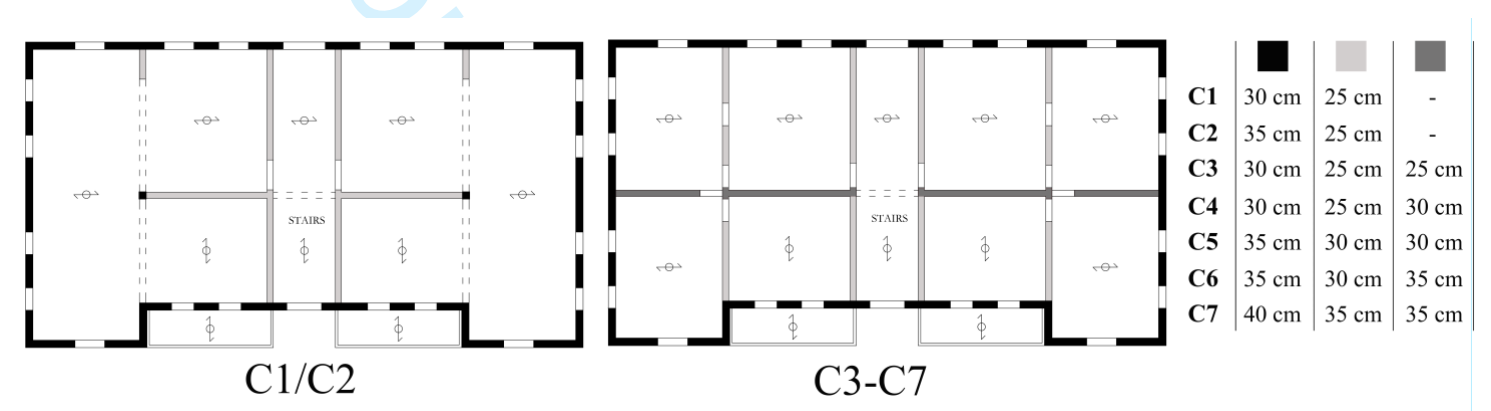

Figure 2. Structural configurations derived from the "C" type architectural configuration: a) $\mathrm{C} 1$ and $\mathrm{C} 2$ with internal r.c. beams and columns; b) $\mathrm{C} 3$ to $\mathrm{C} 7$ with internal masonry walls.

The adopted values of material mechanical properties were assumed consistently with the selected construction technique, making sure that they would respect the minimum code requirements in terms of mortar and unit strength, for new buildings in seismic areas.

A mortar with mean compressive strength equal to $10 \mathrm{MPa}$ was used, with perforated clay units with a characteristic compressive strength $f_{b k}=8 \mathrm{MPa}$. From interpolation of values reported in NTC08, they correspond to a characteristic value of masonry compressive strength $f_{k}=4.66 \mathrm{MPa}$ and a characteristic value of initial shear strength $f_{v k 0}=0.20 \mathrm{MPa}$. A realistic characteristic horizontal compressive strength $f_{b k}^{\prime}=$ 
1.5 MPa was adopted for this type of units. As suggested in NTC08, the Young and the shear moduli were estimated as $E=1000 \cdot f_{k}=4660 \mathrm{MPa}$ and $G=0.4 \cdot E=1864 \mathrm{MPa}$. A specific weight of masonry of $9 \mathrm{kN} / \mathrm{m}^{3}$ was also assumed.

For "E" buildings, dead and permanent loads consisted of $6.0 \mathrm{kN} / \mathrm{m}^{2}$ at intermediate floors, $7.5 \mathrm{kN} / \mathrm{m}^{2}$ at the roof level (sum of attic and roof) and $6 \mathrm{kN} / \mathrm{m}^{2}$ at stairs and balconies, whereas for "C" and "I" buildings, they consisted of $5.5 \mathrm{kN} / \mathrm{m}^{2}$ at intermediate floors, $4.1 \mathrm{kN} / \mathrm{m}^{2}$ at the roof level (flat terrace roof) and $5.5 \mathrm{kN} / \mathrm{m}^{2}$ at stairs and balconies. For all building configurations (residential), imposed loads consisted of $2.0 \mathrm{kN} / \mathrm{m}^{2}$ at all levels and $4.0 \mathrm{kN} / \mathrm{m}^{2}$ on stairs and balconies, with combination coefficients equal to 0.3 and 0.6 , respectively. The total seismic mass of each building is summarized in Table 3.

Table 3. Total mass (in tons) of the considered building models.

\begin{tabular}{c|c|c|c|c|c|c|c|c|c|c|c|c|c}
\hline Building & C1 & C2 & C3 & C4 & C5 & C6 & C7 & E2 & E5 & E8 & E9 & I1 & I2 \\
\hline 2-stories & 364.8 & 381.5 & 379.4 & 376.5 & 399.3 & 403.7 & 421.8 & 364.0 & 326.6 & 543.2 & 591.7 & 249.7 & - \\
\hline 3-stories & 589.0 & 600.8 & 620.4 & 619.8 & 655.2 & 661.0 & 691.0 & 548.7 & 484.2 & 804.9 & 877.6 & - & 336.4 \\
\hline
\end{tabular}

For reinforced concrete elements, a characteristic concrete compressive strength $f_{c k}=20 \mathrm{MPa}$ was adopted for "C" and "I" buildings, whereas $f_{c k}=25 \mathrm{MPa}$ was adopted for "E" buildings. Steel bars with a characteristic yielding strength $f_{y k}=450 \mathrm{MPa}$ were used for all configurations.

The aim of the design - with each of the methods discussed in the following sections - was to obtain building configurations barely complying with code requirements, making sure they were not excessively over-designed.

\subsection{Rules for Simple Masonry Buildings}

For each considered regular building configuration, Table 4 reports the percentages of shear wall area to the total floor area, in each direction, and maximum peak ground 
acceleration on soil $\left(a_{g} S\right)$, depending on the number of stories and shear wall area. The table also reports, the sites in which each building barely complies with code requirements, indicating into brackets the value of seismic hazard (in terms of $a_{g} S$ ) for each site.

Table 4. Percentage of shear wall area over the total floor area for each configuration and corresponding maximum value of $a_{g} S$ according to rules for simple buildings in NTC08. The last two columns identify sites in which each building barely complies with code requirements (i.e. meaningful design)

\begin{tabular}{|c|c|c|c|c|c|c|c|}
\hline \multirow{2}{*}{ Building } & \multirow{2}{*}{$\begin{array}{c}\text { Ares, } \mathbf{X} \\
{[\%]} \\
\end{array}$} & \multirow{2}{*}{\begin{tabular}{|c} 
Ares,Y \\
{$[\%]$} \\
\end{tabular}} & \multirow{2}{*}{\begin{tabular}{|l} 
Ares \\
{$[\%]$} \\
\end{tabular}} & \multicolumn{2}{|c|}{ Max agS [g] } & \multicolumn{2}{|c|}{ Sites with meaningful design $\left(a_{g} S[\mathrm{~g}]\right)$} \\
\hline & & & & 2-storie & 3 -stories & 2-stories & 3 -stories \\
\hline $\mathrm{C} 1$ & 4.40 & 4.40 & 4.40 & 0.1 & - & $\begin{array}{c}\text { MI-C (0.074), CL-A } \\
(0.073), \text { MI-A }(0.049)\end{array}$ & - \\
\hline $\mathrm{C} 2$ & 5.00 & 4.88 & 4.88 & 0.15 & 0.1 & $\begin{array}{c}\text { RM-A (0.121), } \\
\text { CL-C }(0.109)\end{array}$ & $\begin{array}{l}\text { MI-C, CL-A, } \\
\text { MI-A }\end{array}$ \\
\hline $\mathrm{C} 3$ & 5.18 & 5.54 & 5.18 & 0.2 & 0.15 & $\begin{array}{l}\text { RM-C }(0.182), \\
\text { NA-A }(0.168)\end{array}$ & RM-A, CL-C \\
\hline $\mathrm{C} 4$ & 5.53 & 5.54 & 5.53 & 0.25 & 0.2 & NA-C (0.245) & RM-C, NA-A \\
\hline $\mathrm{C} 5$ & 6.12 & 6.64 & 6.12 & 0.3 & 0.25 & AQ-A (0.261) & NA-C \\
\hline C6 & 6.51 & 6.64 & 6.51 & 0.45 & 0.3 & $\mathrm{AQ}-\mathrm{C}(0.347)$ & AQ-A \\
\hline $\mathrm{C} 7$ & 7.15 & 7.77 & 7.15 & 0.4725 & 0.35 & - & $\mathrm{AQ}-\mathrm{C}$ \\
\hline E2 & 6.30 & 6.20 & 6.20 & 0.3 & 0.25 & AQ-A & NA-C \\
\hline E8 & 5.05 & 5.83 & 5.05 & 0.2 & 0.15 & RM-C, NA-A & RM-A, CL-C \\
\hline E9 & 4.85 & 5.72 & 4.85 & 0.15 & 0.1 & RM-A, CL-C & $\begin{array}{l}\text { MI-C, CL-A, } \\
\text { MI-A }\end{array}$ \\
\hline
\end{tabular}

It can be noted that the three-story " $\mathrm{C} 1$ " configuration cannot be designed as a simple building in any of the considered sites, since its resistant masonry area is lower than the minimum required by the code (i.e. $4.5 \%$ ).

\subsection{Linear Static Analysis with and without Force Redistribution}

The "C" and "E" type and buildings, with either two- and three-story, were designed with linear static analysis.

3D structural models of the building were realized using both equivalent frame (EF) and cantilever (C) modeling approach. Floors were modelled as infinitely rigid diaphragms in their plane and cracked sections were assumed in the calculations, by introducing a stiffness reduction coefficient equal to 0.5 . 
As already mentioned, the Italian building code does not force all the necessary modelling choices. The solutions herein adopted for the various analysed buildings reflects what is most currently used in the engineering practice:

i) diaphragms modelled as infinitely rigid in their plane;

ii) roof structure not modeled in detail but represented by a rigid diaphragm connecting the wall top at the attic/roof level, with tributary mass/load applied at the wall-diaphragm connection points;

iii) out-of-plane stiffness contribution neglected;

iv) effective length of r.c. beams assumed equal to the distance between end nodes (i.e. the nodes of the equivalent frame, located at the floor levels either at mid-length of masonry piers or at the intersection of perpendicular walls);

v) wall-to-wall connection assumed as fully effective;

vi) effective height of piers equal to the net inter-story height, or computed according to Lagomarsino et al. (2013), in configurations without ("E”) and with ("C") spandrels, respectively;

vii) opening offsets related to the presence of staircases included in the equivalent frame models (particularly relevant for "C" configurations, with spandrels);

viii) distribution of loads to vertical load-bearing elements unidirectional for "C" configurations; for "E" configurations, a partly bidirectional load sharing was considered.

Concerning issue iv), it is interesting to note that, although in reality the ring beam is continuous at the floor level, it is conceivable to assume various effective lengths (e.g. equal to the distance between two adjacent nodes, the width of the openings, or an 
intermediate length between the two). These possibilities correspond to different hypotheses on the effect of the interaction between the wall and the r.c. ring beam, in particular at the opening levels (Beyer and Dazio, 2012).

Spandrels were absent in the "E"-type configurations, due to the reduced thickness of masonry below windows and the presence of coffered roller blinds above, reducing the transversal section of spandrels to the section of the ring beam.

Aspects (iv), (v) and (vii) are discussed in more detail in Cattari et al. (2018), where they are treated as epistemic uncertainties, by considering different plausible assumptions. For the design, the options most frequently selected by professional engineers were instead adopted.

In the case of the "E" buildings (both two- and three-story), the LSA method was applied also by considering the force redistribution. For that, the cantilever models were used, because the absence of horizontal elements connecting masonry piers guarantees a constant level of axial compression in the elements, which does not affect the strength redistribution, facilitating the application of the procedure. The force redistribution is applied by guaranteeing the global equilibrium and the strength verifications of each element, under the design load condition.

Figure 3 reports a view of two 3D models of the considered configurations. 


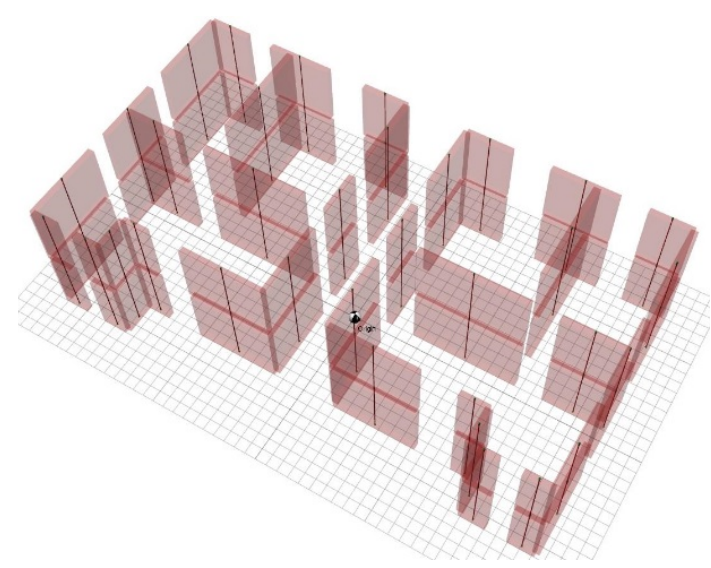

(a)

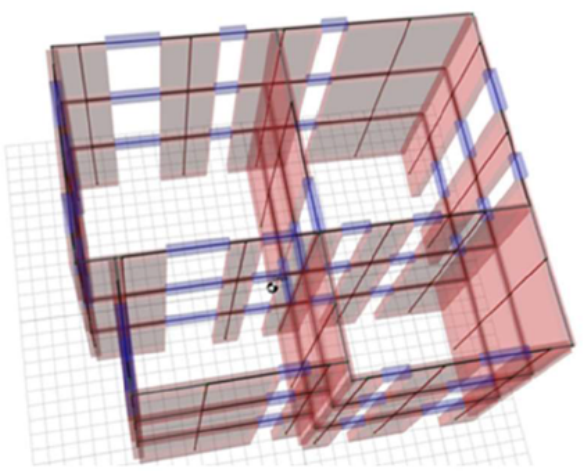

(b)

Figure 3. Examples of structural models adopted for the design according to LSA: a) cantilever model of E8 configuration; b) equivalent frame model of E5 configuration

The values of the initial period were estimated using the simplified formula of NTC08 and EC8, i.e. $T_{1}=0.05 H^{0.75}$ with $H$ the total height of the building, in $\mathrm{m}$. The values obtained were equal to $0.194 \mathrm{~s}$ for two-story buildings and $0.264 \mathrm{~s}$ for three-story buildings. The initial periods evaluated by means of modal analysis resulted instead to be lower than the code values, i.e. $0.141-0.151$ s for two-story "E" buildings, $0.083-0.104 \mathrm{~s}$ for two-story "C" buildings, $0.215-0.235$ s for three-story "E" buildings and 0.129 0.153 s for three-story "C" buildings. The lower values associated with "C" buildings can be justified by the presence of spandrels.

A global safety factor $\alpha$ was defined as the ratio between the PGA corresponding to the attainment of the LS limit state and the design PGA for a return period of 475 years (indicated as $a_{g} S_{475}$ in Table 5). Buildings barely complying with code requirements correspond to values of $\alpha$ not significantly larger than unity.

Table 5 summarizes the meaningful building-site combinations obtained from design with LSA, with and without force redistribution, with indication of the corresponding values of $\alpha$ into brackets (in the case of force redistribution, $\alpha=1$ by 
definition and hence it is not reported). As highlighted in the table by means of grey shadows, if a building configuration can be designed at a given site, it could obviously be designed as well in any site with lower seismic hazard, but it would correspond to a high value of $\alpha$.

Table 5. Meaningful building-site combinations obtained from design with linear static analysis, with equivalent frame model (EF), cantilever model (C) and cantilever model with force redistribution $(\mathrm{C}(\mathrm{R}))$. Values into brackets indicate the corresponding safety factor $\alpha$. Grey-shaded cells correspond to combinations overdesigned using LSA.

\begin{tabular}{|c|c|c|c|c|c|c|c|c|c|c|c|}
\hline & MI-A & CL-A & MI-C & CL-C & RM-A & NA-A & RM-C & NA-C & AQ-A & AQ-C \\
\hline & & $0.049 \mathrm{~g}$ & $0.073 \mathrm{~g}$ & $0.074 \mathrm{~g}$ & $0.109 \mathrm{~g}$ & $0.121 \mathrm{~g}$ & $0.168 \mathrm{~g}$ & $0.182 \mathrm{~g}$ & $.245 \mathrm{~g}$ & $0.261 \mathrm{~g}$ & $0.347 \mathrm{~g}$ \\
\hline \multirow{8}{*}{ 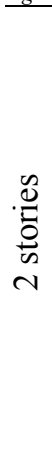 } & C4 & $\begin{array}{c}\mathrm{EF}(1.14), \\
\mathrm{C}(1.02)\end{array}$ & - & - & - & - & - & - & - & - & - \\
\hline & C5 & $\mathrm{C}(1.00)$ & - & - & - & - & - & - & - & - & - \\
\hline & C6 & $C(1.14)$ & - & - & - & - & - & - & - & - & - \\
\hline & C7 & $C(1.10)$ & $\mathrm{EF}(1)$ & - & - & - & - & - & - & - & - \\
\hline & E2 & & $\mathrm{C}(\mathrm{R})$ & $\begin{array}{l}\mathrm{EF}(1.14), \\
\mathrm{C}(\mathrm{R})\end{array}$ & - & - & - & - & - & - & - \\
\hline & E5 & & $\mathrm{C}(\mathrm{R})$ & $\mathrm{C}(\mathrm{R})$ & - & - & - & - & - & - & - \\
\hline & E8 & & & & $\mathrm{C}(\mathrm{R})$ & $C(R)$ & $C(R)$ & - & - & - & - \\
\hline & E9 & & & & $\begin{array}{c}\mathrm{EF}(1.15), \\
\mathrm{C}(\mathrm{R})\end{array}$ & $\begin{array}{c}\mathrm{EF}(1.07), \\
\mathrm{C}(\mathrm{R})\end{array}$ & $\mathrm{C}(\mathrm{R})$ & $\mathrm{C}(\mathrm{R})$ & & & \\
\hline \multirow{8}{*}{$\begin{array}{l}\frac{\mathscr{v}}{0} \\
\frac{0}{\infty} \\
m \\
m\end{array}$} & $\mathrm{C} 4$ & - & - & - & - & - & - & - & - & - & - \\
\hline & C5 & - & - & - & - & - & - & - & - & - & - \\
\hline & C6 & $C(1.02)$ & - & - & - & - & - & - & - & - & - \\
\hline & C7 & $\mathrm{C}(1.02)$ & - & - & - & - & - & - & - & - & - \\
\hline & E2 & $\mathrm{C}(1.10)$ & $\begin{array}{c}\mathrm{EF}(1.07), \\
\text { C(R) }\end{array}$ & $\begin{array}{c}\mathrm{EF}(1.03), \\
\mathrm{C}(\mathrm{R})\end{array}$ & - & - & - & - & - & - & - \\
\hline & E5 & $\begin{array}{c}\mathrm{EF}(1.02), \\
\mathrm{C}(\mathrm{R})\end{array}$ & $\mathrm{C}(\mathrm{R})$ & $\mathrm{C}(\mathrm{R})$ & - & - & - & - & - & - & - \\
\hline & E8 & & $C(1.10)$ & $\mathrm{C}(1.07)$ & $\begin{array}{c}\mathrm{EF}(1.13), \\
\mathrm{C}(\mathrm{R})\end{array}$ & $\begin{array}{c}\mathrm{EF}(1.02) \\
\mathrm{C}(\mathrm{R})\end{array}$ & - & - & - & - & - \\
\hline & E9 & & $\begin{array}{l}\mathrm{EF}(1.12), \\
\mathrm{C}(1.18)\end{array}$ & $\begin{array}{c}\mathrm{EF}(1.09), \\
\mathrm{C}(1.14)\end{array}$ & $C(R)$ & $\mathrm{C}(\mathrm{R})$ & $\mathrm{C}(\mathrm{R})$ & - & - & - & - \\
\hline
\end{tabular}

The results obtained show that the use of LSA allows designing URM buildings only in sites with low seismic hazard; indeed, some of the considered building configurations (e.g. C1, C2 and C3, which indeed are not reported in the table) cannot even be designed in the very low seismicity site of Milan. The use of force redistribution 
mitigates these outcomes, with the possibility of designing some building configurations even in Rome and Naples, i.e. in sites characterized by moderate seismic hazard.

\subsection{Nonlinear Static Analysis (Pushover)}

The different building configurations were designed also by using NLSA. This design method can be used both in case of regular buildings and in case of buildings with irregularity in plan and elevation; for this reason, it was applied to the "C", "I" and "E" type configurations and considering both 2 and the 3 -storey buildings.

3D structural models were realized using the equivalent frame approach, with the hypotheses discussed in the section on LSA. For "I" configurations, the options discussed with reference to "C" configurations were adopted. Figure 4 shows two examples of the models used for NLSA.
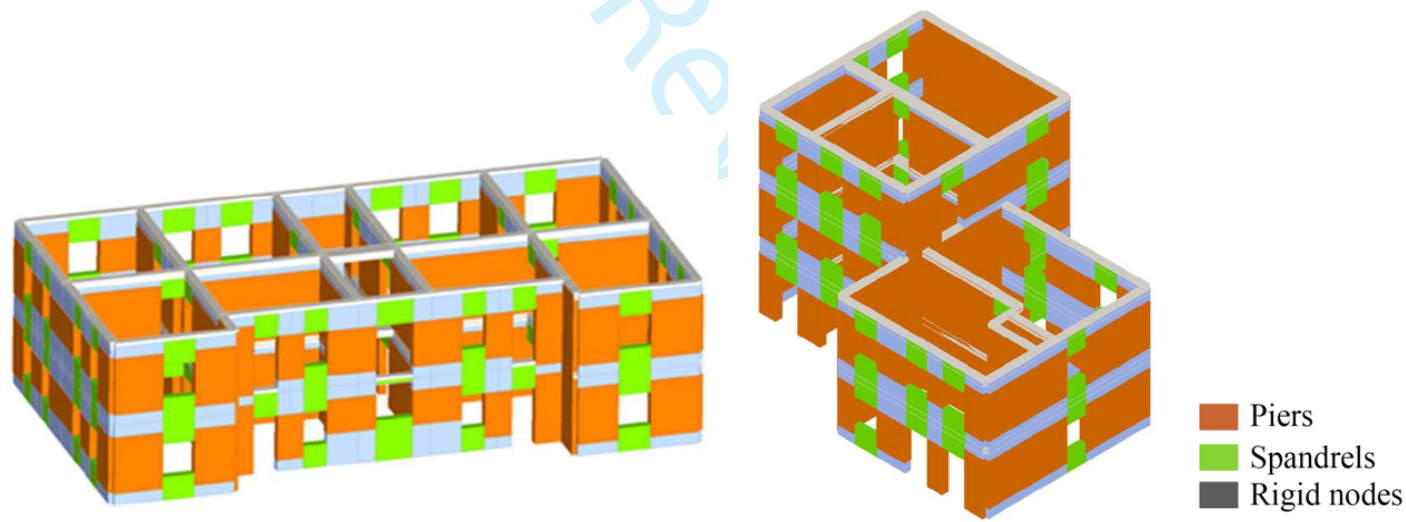

Figure 4. Examples of structural models adopted for NLSA ("C" and "I" type configurations)

For each configuration, pushover analyses were carried out considering both $\mathrm{X}$ and $\mathrm{Y}$ directions and using two load patterns, i.e. mass proportional and inverted triangular. The latter was assumed as an approximation of the modal load pattern, as allowed by NTC08. The effect of accidental eccentricity was also taken into account. 
Table 5 reports the structural configurations allowing to comply with code requirements in the different sites and the corresponding values of the safety factor. Bold characters indicate solutions that are not excessively over-designed. In few cases, the safety factors were slightly higher than 1.2 and it was not possible to further reduce them, due to constraints associated with the design for vertical loads and limitations imposed by NTC08 (e.g. minimum thickness, etc.). For example, for "C" type configurations, even the "minimum" conceivable building, $\mathrm{C} 1$ (obtained by replacing some internal walls with r.c. columns and beams), resulted to be over-designed in many sites (with values of the safety factor higher than 1.5). This was observed for increasing seismicity sites up to the level of Rome-soil C, in case of 2-story buildings, and up to Naples-soil A in case of 3story buildings.

Table 6. Values of the safety factor $\alpha$ obtained from design of two-story buildings with NLSA.

\begin{tabular}{|c|c|c|c|c|c|c|}
\cline { 2 - 7 } \multicolumn{1}{c|}{$\begin{array}{c}\text { Building } \\
\text { Type }\end{array}$} & \multicolumn{7}{|c|}{ Site } \\
\cline { 2 - 7 } 2 stories & NA-A & RM-C & NA-C & AQ-A & AQ-C \\
\cline { 2 - 7 } & $\mathrm{C}$ & $\mathrm{C} 1>1.5$ & $\mathrm{C} 1>1.5$ & C1-1.22 & C1-1.15 & $\mathbf{C 3 - 1 . 2 2}$ \\
\cline { 2 - 7 } & $\mathrm{I} 1$ & $>1.5$ & $>1.5$ & $>1.5$ & $>1.5$ & $\mathbf{1 . 2 8}$ \\
\cline { 2 - 7 } & $\mathrm{E} 2$ & $>1.5$ & $>1.5$ & $>1.5$ & $>1.5$ & $\mathbf{1 . 0 4}$ \\
\cline { 2 - 7 } & $\mathrm{E} 5$ & $>1.5$ & $>1.5$ & $>1.5$ & $>1.5$ & $\mathbf{1 . 0 8}$ \\
\cline { 2 - 7 } & $\mathrm{E} 8$ & $>1.5$ & $>1.5$ & $>1.5$ & $>1.5$ & $\mathbf{1 . 1 2}$ \\
\cline { 2 - 7 } & $\mathrm{E} 9$ & $>1.5$ & $>1.5$ & $>1.5$ & $>1.5$ & $\mathbf{1 . 1 0}$ \\
\hline \multirow{5}{*}{ stories } & $\mathrm{C}$ & $\mathrm{C} 1>1.5$ & $\mathbf{C 1} \mathbf{- 1 . 2 8}$ & $\mathbf{C 3 - 1 . 1 7}$ & $\mathbf{C 1 - 1 . 0 1}$ & $\mathrm{C} 1<1$ \\
\cline { 2 - 7 } & $\mathrm{I} 2$ & $>1.5$ & $>1.5$ & $\mathbf{1 . 2 7}$ & $<1$ & $<1$ \\
\cline { 2 - 7 } & $\mathrm{E} 2$ & $>1.5$ & $>1.5$ & $\mathbf{1 . 0 1}$ & $\mathbf{1 . 1 6}$ & $<1$ \\
\cline { 2 - 7 } & $\mathrm{E} 5$ & $\mathbf{1 . 0 0}$ & $<1$ & $<1$ & $<1$ & $<1$ \\
\cline { 2 - 7 } & $\mathrm{E} 8$ & $>1.5$ & $>1.5$ & $\mathbf{1 . 1 4}$ & $\mathbf{1 . 3 2}$ & $<1$ \\
\cline { 2 - 7 } & $\mathrm{E} 9$ & $>1.5$ & $>1.5$ & $\mathbf{1 . 3 3}$ & $>1.5$ & $<1$ \\
\hline
\end{tabular}

2-story "C" buildings resulted to be over-designed at all sites up to NA-C, whereas all 2story "E" buildings were over-designed at all sites, except for AQ-C. For the 3-story "C" type buildings, none of the considered configurations was verified with NLSA in L'Aquila (soil type C), while the C1 configuration can be used in L'Aquila (soil type A) 
and in Rome (soil type C); in all the other sites the defined configurations presented a safety factor higher than 1.5 . It can also be seen that the 3 -story $\mathrm{C} 1$ configuration, which cannot be designed in any site as a simple building, according to NLSA can be located even in L'Aquila, soil type A. 3-story "E5" irregular building can be designed up to NAA, whereas the other "E" type buildings can be designed until NA-C (E2, E8, E9) or AQA (E2, E8).

Considering the "I" type irregular buildings, it comes out that the I1 2-storey configuration can be considered only in L'Aquila (soil type C), since it is excessively over dimensioned in the other sites. On the other hand, the I2 3-storey irregular building was selected only for Naples (soil type C), as it is not code-compliant for sites with a higher seismic hazard and it is excessively over-dimensioned for sites with lower seismic hazard.

As an example, Figure 5 shows some of the pushover curves of the "C" type configurations, in terms of overall base shear versus top displacement, computed as the average of all nodes weighted on their tributary mass. It may be observed that the curves referring to the $\mathrm{C} 1$ and $\mathrm{C} 2$ configurations present a lower strength with respect to the curves related to the other ones $(\mathrm{C} 3, \mathrm{C} 4, \mathrm{C} 5, \mathrm{C} 6, \mathrm{C} 7)$, due the presence of r.c. beams and columns replacing some internal masonry walls and hence reducing the area of shear walls, especially in the y direction. The increase in the wall thickness (from C3 to C7 configuration) corresponds to a relatively limited increase of the overall base shear, being the increase in the resistant area only relevant for shear failure modes and not for rocking mechanisms. On the other hand, the increase in lateral strength is partly counterbalanced by the increase of inertial forces associated with the incremented mass of structural walls. 


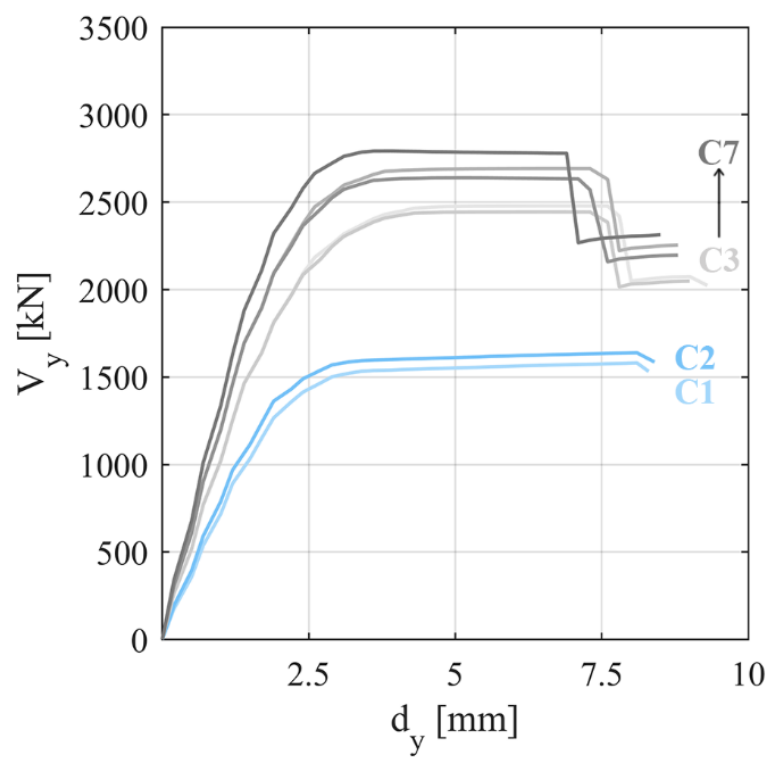

(a)

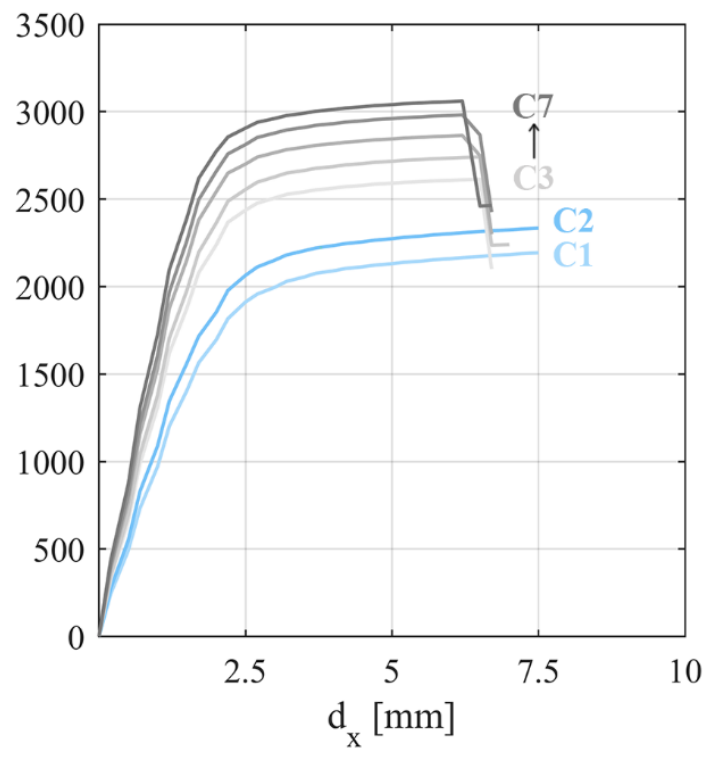

(b)

Figure 5. Pushover curves of the 3-storey ' $\mathrm{C}$ '" type configurations: (a) inverse triangular distribution and $y$ positive direction; (b) mass-proportional distribution and $x$ positive direction.

\section{Identification of Relevant Building-Site Combinations}

Table 7 and Table 8 summarize, for each site, the meaningful configurations, i.e. buildings that are barely able to sustain the design seismic action corresponding to the different sites according to the different analysis methods. 
Table 7. 2-story configurations that can barely sustain the design seismic action at the different sites, with the different analysis methods ( $\mathrm{SB}=$ rules for simple buildings, LSA $=$ linear static analysis, with equivalent frame $(\mathrm{EF})$ or cantilever $(\mathrm{C})$ model (in italics when force redistribution is applied) and NLSA = nonlinear static analysis). Grey-shaded cells correspond to sites for which all building configurations are overdesigned with NLSA.

\begin{tabular}{|c|c|c|c|c|c|}
\hline Site & $\begin{array}{c}\boldsymbol{a}_{g} \boldsymbol{S} \\
\mathbf{g}]\end{array}$ & SB & LSA|EF & LSA|C & NLSA \\
\hline MI-A & 0.049 & C1 & C4 & C4, C5, C6, C7 & \\
\hline CL-A & 0.073 & C1 & C7 & $E 2, E 5$ & \\
\hline MI-C & 0.074 & C1 & E2 & $E 2, E 5$ & \\
\hline CL-C & 0.109 & C2, E9 & E9 & $E 8, E 9$ & \\
\hline RM-A & 0.121 & C2, E9 & E9 & $E 8, E 9$ & \\
\hline NA-A & 0.168 & C3, E8 & - & $E 8, E 9$ & \\
\hline RM-C & 0.182 & C3, E8 & - & $E 9$ & \\
\hline NA-C & 0.245 & C4 & - & - & C1 \\
\hline AQ-A & 0.261 & C5, E2 & - & - & C1 \\
\hline AQ-C & 0.347 & C6 & - & - & $\begin{array}{c}\text { C3, I1, E2, } \\
\text { E5, E8, E9 }\end{array}$ \\
\hline
\end{tabular}

Table 8. 3-story configurations that can barely sustain the design seismic action at the different sites, with the different analysis methods ( $\mathrm{SB}=$ rules for simple buildings, LSA = linear static analysis, with equivalent frame (EF) or cantilever $(\mathrm{C})$ model (in italics when force redistribution is applied) and NLSA = nonlinear static analysis). Grey-shaded cells correspond to sites for which all building configurations are overdesigned with NLSA.

\begin{tabular}{|c|c|c|c|c|c|}
\hline Site & $\begin{array}{c}\mathbf{a g} \mathbf{S} \\
{[\mathbf{g}]}\end{array}$ & $\mathbf{S B}$ & $\mathbf{L S A} \mid \mathbf{E F}$ & $\mathbf{L S A} \mid \mathbf{C}$ & NLSA \\
\hline MI-A & 0.049 & C2, E9 & E5 & C6, C7, E2, E5 & \\
\hline CL-A & 0.073 & C2, E9 & E2, E9 & E2, E5, E8, E9 & \\
\hline MI-C & 0.074 & C2, E9 & E2, E9 & E2, E5, E8, E9 & \\
\hline CL-C & 0.109 & C3, E8 & E8 & E8, E9 & \\
\hline RM-A & 0.121 & C3, E8 & E8 & E8, E9 & \\
\hline NA-A & 0.168 & C4 & - & E9 & E5 \\
\hline RM-C & 0.182 & C4 & - & - & C1 \\
\hline NA-C & 0.245 & C5, E2 & - & - & $\begin{array}{c}\text { C3, I2, E2, } \\
\text { E8 }\end{array}$ \\
\hline AQ-A & 0.261 & C6 & - & - & C1, E2 \\
\hline AQ-C & 0.347 & C7 & - & - & - \\
\hline
\end{tabular}

As could be expected, different design methods correspond to even significantly different levels of conservativeness. This implies that, depending on the selected design 
approach, the same building configuration could not even comply with the code requirements in low-seismic areas or, otherwise, it could result to be over-designed even at moderate-to-high seismic hazard sites. This is evident from Figure 6, showing the different " $C$ " structural configurations that can be barely designed at the different sites (whose values of $a_{g} S$ are reported on the right vertical axis), using the different analysis methods (legend on top). The black histograms indicate the percentage of resisting masonry area over the total floor area obtained at the different sites. It can be noted that the percentage of resisting area is very large and uncorrelated to seismicity in case of LSA, whereas it is obviously correlated in case of SB. For NLSA, it can be seen that, for a given level of seismicity, the area is significantly reduced with respect to the other methods.

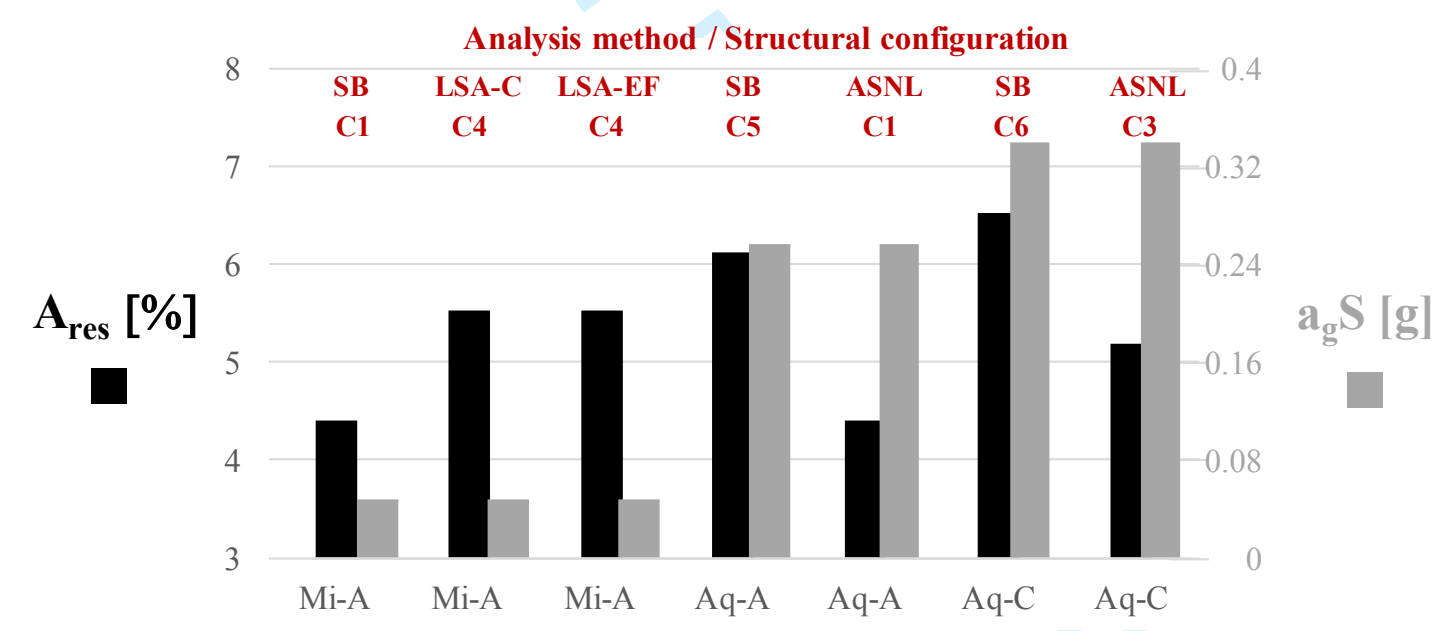

Figure 6. Overview of design outcomes for the " $\mathrm{C}$ " type configurations obtained with different analysis methods, highlighting the variation in the percentage of resisting masonry area over the total floor area (black) compared to seismicity (grey).

Meaningful building-site combinations identified in Tables 7 and 8 have been then included in the final assessment through nonlinear dynamic analyses, illustrated in Cattari et al. (2018). 


\section{Conclusions}

A set of structural configurations, selected to be representative of modern URM buildings in different parts of Italy, were designed according to the different methods allowed by NTC08. The results seem to indicate that, as the level of seismic hazard increases, it is necessary to resort to a design method with an implicitly embedded lower level of conservativeness, in order to be able to fulfill the code requirements. In particular, in higher seismicity sites, NLSA is the only possibility for designing buildings that cannot be classified as "simple buildings". On the other hand, linear analysis methods are much more conservative with respect to the application of SB rules and NLSA, being in fact applicable in low seismicity sites only. The use of less conservative methods in higher seismicity sites leads to non-uniform levels of seismic protection, with the consequence that the higher the seismicity is, the lower the level of safety, i.e. the higher is the risk implicitly embedded in the design.

The meaningful building configurations resulting from the design with the different methods were analyzed to evaluate the level of risk implicit in them and, in particular, whether this level is uniform all over Italy. This paper has shown that the level of seismic risk is not uniform even in the same site, due to the alternative possible design methods. The assessment of the actual performance of designed building configurations will be discussed in a companion paper (Cattari et al. 2018). The effects on the calculated level of seismic risk are discussed in Iervolino et al. (2018) and compared with the corresponding results for other structural typologies.

\section{Acknowledgements}

The study presented in this article was developed within the activities of the DPCReLUIS-EUCENTRE 2014-2018 research program, funded by Presidenza del Consiglio dei Ministri - Dipartimento della Protezione Civile; however, opinions and conclusions 
do not necessarily reflect those of the funding entity.

\section{References}

Andreaus, U. [1996] "Failure Criteria for Masonry Panels under In-Plane Loading," ASCE Journal of Structural Engineering, 122(1): 37-46.

Beyer, K., Dazio, A. [2012] "Quasi-Static Monotonic and Cyclic Tests on Composite Spandrels," Earthquake Spectra 28(3):885-906

Beyer, K., Mangalathu, S. [2013]. "Review of strength models for masonry spandrels," Bulletin of Earthquake Engineering 11(2): 521-542.

Calderini, C., Cattari, S., and Lagomarsino, S. [2009] "In-plane strength of unreinforced masonry piers," Earthquake Engineering and Structural Dynamics 38(2):243-67

Cattari, S., Camilletti, D., Lagomarsino, S., Bracchi, S., Rota, M., Penna, A. [2018] "Masonry Italian code-conforming buildings. Part 2: nonlinear modelling and time-history analysis.” Journal of Earthquake Engineering. (In review)

Causevic, M., Mitrovic, S. [2011]. "Comparison between non-linear dynamic and static seismic analysis of structures according to European and US provisions," Bulletin of Earthquake Engineering 9:467-489.

Corigliano, M., Lai, C. G., Rota, M., \& Strobbia, C. L. [2012] “ASCONA: Automated Selection of COmpatible Natural Accelerograms." Earthquake Spectra 28(3): 965-987.

Costa, A.A., Penna, A., and Magenes, G. [2011]. "Seismic performance of autoclaved aerated concrete (AAC) masonry: from experimental testing of the in-plane capacity of walls to building response simulation," Journal of Earthquake Engineering 15(1): 1-31.

De Luca, F., Vamvatsikos, D., Iervolino, I. [2013] "Near-optimal piecewise linear fits of static pushover capacity curves for equivalent SDOF analysis," Earthquake Engineering and Structural Dynamics 42:523-543.

DeJong, M., Penna, A. [2016]. "Design of masonry structures” in A. Y. Elghazouli (Ed.) Seismic design of buildings to Eurocode 8, pp. 235-254, CRC Press

EN1996-1-1 [2004]. Eurocode 6: design of masonry structures, Part 1: general rules for reinforced and unreinforced masonry structures, CEN, Brussels

EN1998-1 [2004]. Eurocode 8: design of structures for earthquake resistance - Part 1: general rules, seismic actions and rules for buildings, CEN, Brussels 
EN1998-3 [2005] Eurocode 8: design of structures for earthquake resistance - Part 3: Assessment and retrofitting of buildings. CEN, Brussels

Fajfar, P. [2000]. "A nonlinear analysis method for performance based seismic design," Earthquake Spectra 16, (3): 573-592.

Gams, M., Triller, P., Lutman, M., and Snoj, J. [2016] "Seismic behaviour of URM walls: analysis of a data base," Proc. of the 16th International Brick and Block Masonry Conference, IBMAC 2016, Padua, Italy.

Graubner, C.A., Kranzler, T. [2006] "In-Plane Bearing Capacity of Unreinforced Masonry Panels," Proc. of the $7^{\text {th }}$ International Masonry Conference, London, UK.

Guerrini, G., Graziotti, F., Penna, A., and Magenes, G. [2017] "Improved evaluation of inelastic displacement demands for short-period masonry structures," Earthquake Engineering and Structural Dynamics 46(9): 1411-1430.

Iervolino I., Spillatura A., Bazzurro P. [2018] "Seismic structural reliability of codeconforming Italian buildings". Journal of Earthquake Engineering. (In review)

Jäger, A., Gams, M. (2016) "Practical design of masonry subjected to horizontal loads based on Eurocode 6 shear model", Proc. of the 16th International Brick and Block Masonry Conference, IBMAC 2016, Padua, Italy.

Kalkan, E., Kunnath, S. [2006]. “Adaptive modal combination procedure for nonlinear static analysis of building structures," ASCE Journal of Structural Engineering, 132(11): 1721-1731

Lagomarsino, S., Cattari, S. [2015] "Seismic performance of historical masonry structures through pushover and nonlinear dynamic analyses" In: A. Ansal (ed.) Perspectives on European Earthquake Engineering and Seismology. 2:265-292, Geotechnical, geological and earthquake engineering 39, Springer Netherlands.

Lagomarsino, S., Penna, A., Galasco, A., and Cattari, S. [2013] "TREMURI program: an equivalent frame model for the nonlinear seismic analysis of masonry buildings," Engineering Structures 56: 1787-1799

Magenes, G. [2006] "Masonry building design in seismic areas: recent experiences and prospects from a European standpoint," Proc. 1st European Conference on Earthquake Engineering and Seismology, Geneva, Switzerland.

Magenes, G. [2010] "Earthquake resistant design of masonry structures: rules, backgrounds, latest findings", Proc. 8th International Masonry Conference, Dresden, Germany. 
Magenes, G., Calvi, G.M. [1997] "In-plane seismic response of brick masonry walls. Earthquake Engineering and Structural Dynamics 26:1091-112.

Magliulo, G., Bellotti, D., Cimmino, M., and Nascimbene, R. [2018] "Modeling and seismic response analysis of RC precast Italian code-conforming buildings," Journal of Earthquake Engineering, in review.

Mann, W., Mueller, H. [1982]. "Failure of shear-stressed masonry: an enlarged theory, tests and application to shear walls," Proc. of the British Ceramical Society 30: $223-235$.

Manzini, C.F., Morandi, P., Magenes, G. and Calliari, R. [2013] “ANDILWall (versione 3.0) Software di calcolo e verifica di edifici in muratura ordinaria, armata o mista - Manuale d'uso" (in Italian).

Marino, S., Cattari, S., and Lagomarsino, S. [2018] "Use of non-linear static procedures for irregular URM buildings in literature and codes," Proc. of the 16th European Conference on Earthquake Engineering, Thessaloniki, Greece.

Miranda, E. [1993] "Evaluation of site-dependent inelastic seismic design spectra," ASCE Journal of Structural Engineering. 119(5):1319-1338.

Morandi, P., Albanesi, L., Graziotti, F., Li Piani, T., Penna, A., Magenes, G. [2018] "Development of a dataset on the in-plane experimental response of URM piers with bricks and blocks," Construction and Building Materials (under review).

Mouyiannou, A., Rota, M., Penna, A., and Magenes, G. [2014] "Identification of suitable limit states from nonlinear dynamic analyses of masonry structures," Journal of Earthquake Engineering. 18(2):231-263.

NTC08 [2008] "Decreto ministeriale 14/1/2008: Norme tecniche delle costruzioni. Ministero delle Infrastrutture e dei trasporti”, S.O. No. 30 alla G.U. No. 29 del 4/2/2008, Ministero delle Infrastrutture e dei Trasporti, Rome, Italy (in Italian).

NTC18 [2018] "Decreto ministeriale 17/1/2018: Aggiornamento delle «Norme tecniche per le costruzioni»", S.O. alla G.U. No. 42 del 20/2/2018, Ministero delle Infrastrutture e dei Trasporti, Rome, Italy (in Italian).

Petry, S., Beyer, K. [2014] "Influence of boundary conditions and size effect on the drift capacity of URM walls," Engineering Structures 65:76-88.

Ragni, L., Cardone, D., Conte, N., Dall'Asta, A., Di Cesare, A., Flora, A., Leccese, G., Micozzi, F., Ponzo, F.C., [2018] "Modeling and seismic response analysis of Italian code-conforming base-isolated buildings," Journal of Earthquake Engineering. (In review) 
Ricci, P., Manfredi, V., Noto, F., Terrenzi, M., Celano, F., De Risi, M.T., Camata, G., Franchin, P., Magliulo, G., Masi, A., Mollaioli, F., Spacone, E., Verderame, G.M. [2018] "Reinforced concrete Italian code-conforming buildings. Part 2: nonlinear response analysis," Journal of Earthquake Engineering. (In review)

Salmanpour, A. H., Mojsilovic, N., Schwartz, J. [2013] "Deformation capacity of unreinforced masonry walls subjected to in-plane loading: a state-of-the-art review," International Journal of Advanced Structural Engineering 5(1):22.

Scozzese, F., Terracciano, G., Zona, A., Della Corte, G., Dall'Asta, A., Landolfo, R. [2018] "Modelling and seismic response analysis of Italian code-conforming single-storey steel buildings," Journal of Earthquake Engineering. (In review)

Smerzini, C., Galasso, C., Iervolino, I., Paolucci, R. [2014] “Ground Motion Record Selection Based on Broadband Spectral Compatibility," Earthquake Spectra, 30(4): 1427-1448

Snoj, J., Dolšek, M. [2017] "Fragility functions for unreinforced masonry walls made from hollow clay units," Engineering Structures 145:293-304.

STA Data [2017] 3Muri computer program, Release 11.4.0, www.3muri.com

Terrenzi, M., Noto, F., Ricci, P., De Risi, M.T., Manfredi, V., Celano, F., Camata, G., Franchin, P., Magliulo, G., Masi, A., Mollaioli, F., Spacone, E., Verderame G.M. [2018] "Reinforced concrete Italian code-conforming buildings. Part 1: design and modelling," Journal of Earthquake Engineering. (In review)

Tomaževič, M. [1999] Earthquake-Resistant Design of Masonry Buildings, Imperial College Press, London.

Tomaževič, M. [2009]. "Shear resistance of masonry walls and Eurocode 6: shear versus tensile strength of masonry," Materials and Structures, 42(7): 889-907.

Tomaževič, M., Lutman, M., \& Bosiljkov, V. [2006] "Robustness of masonry units and seismic behaviour of masonry walls." Construction and Building Materials 20:1028-1039.

Whittaker, A., Constantinou, M., Tsopelas, P. [1998] "Displacement estimates for performance-based seismic design," ASCE Journal of Structural Engineering. 124(8):905-912. 